Journal of Indonesian Economy and Business

Volume 33, Number 3, 2018, 243 - 256

\title{
THE IMPLEMENTATION OF RISK MANAGEMENT AND ITS EFFECT ON GOOD COOPERATIVE GOVERNANCE AND SUCCESS
}

\author{
Sugiyanto \\ Master of Management, Institut Manajemen Koperasi Indonesia, Indonesia \\ (giyant2000@ikopin.ac.id) \\ Anggi Andriani Rahayu \\ Master of Management, Institut Manajemen Koperasi Indonesia, Indonesia \\ (anggi_andriani93@yahoo.com)
}

\begin{abstract}
The cooperative success must be support by good cooperative governance and implementation of risk management. This study identifies risk management, especially in savings and loan cooperatives, and to test and prove empirically the effects of the implementation of risk management on good cooperative governance and the cooperative success. The research method used a descriptive quantitative analysis and saturation sampling techniques; while the size of the population was 73 persons, consisting of various cooperatives' boards of directors, supervisors, managers, and administrators. The primary data needed in this study were obtained by using a survey method which involved questionnaires and conducting structured interviews. This study uses a statistical approach by using path analysis. The result of this study shows that two categories of risks can be identified, which are minor and insignificant risks. A minor risk includes the credit risk and strategic risk, and an insignificant risk includes six risks: market risk, liquidity risk, operational risk, legal risk, reputation risk and compliance risk. Based on the statistical analysis, the indication is that there is no effect from the implementation of risk management on a cooperative's success, but there is an effect from the implementation of risk management on good cooperative governance, and good cooperative governance has an effect on a cooperative's success. Indirectly, a cooperative's success is not influenced by the implementation of risk management, but it is influenced by the implementation of risk management through good cooperative governance as an intervening variable.
\end{abstract}

Keywords: implementation of risk management, good cooperative governance, cooperative's success JEL Classification: G380, M100, O160 


\section{INTRODUCTION}

The success of cooperative organizations as business entities has been an ongoing problem, despite the fact, there are good-performing cooperatives, which are able to run their activities and achieve their goals. The orientation of a cooperative is as a service provider to its members, rather than it having a for-profit orientation, with the aim of improving the welfare of its members. The cooperative organization consists of two households, i.e., a cooperative enterprise and the members' household, acting as both consumer and producer. Dülfer and Laurinkari (1994) call it the double nature of a cooperative, it is, on the one hand, principally (a) an association, a group in the sociological and socio-psychological sense, whose members are the individuals owning and maintaining the cooperative which, on the other hand, is also (b) a jointly undertaken enterprise on behalf of the members' individual economies (households, individual business), where the owners of the cooperative enterprise are the individual members of the cooperative group; so that the cooperative exists as an economic institution as well as a social institution. As an economic institution/business, it must be run by economic principles that put forward the principle of efficiency, as with other business entities, but the cooperative must also be able to carry out its social functions.

A well-performing cooperative should be able to play its role as an economic institution as well as a social institution, both in its organizational environment and for the surrounding community. Cooperative managers must have a multi-function role of service in order to increase the welfare of the members and help build the national economic order. Thus the manager of the cooperative must play a role in realizing that the purpose of the cooperative is to provide services to its members, advance the cooperative's business and to have an impact on the development of the cooperative's working areas.

To ensure the success of the organization, as well as the cooperative, both must implement good cooperative governance, because the implementation of good cooperative governance is directed at building the culture and awareness of the parties in the cooperative, in order to lead to the achievement of the cooperative's objectives. Based on research conducted by Putra and Simanungkalit (2014), evidence has been found that the implementation of good corporate governance is important for the value of a company. Danoshana and Ravivathani (2013) revealed that the variables of corporate governance significantly impact on a firm's performance.

The presence of good corporate governance is one of the solutions to create and conduct business activities and avoid scandals within a company (Santoso, 2008). Therefore, the cooperative, as an economic and social institution, must be managed with good governance by referring to the values and principles of cooperatives. Governance undertaken by cooperatives should be based on cooperatives as economic and social institutions. Good governance is an important component of corporate risk management, so corporate governance cannot be separated from risk management. Lam (2014) said that corporate governance is an essential component of enterprise risk management because it provides top-down monitoring and management of the risk.

Thus the implementation of risk management becomes increasingly important because the failure to manage risk can result in substantial losses for both the organization and for individuals within the organization, as well as for the cooperatives that have savings and 
loan businesses. The potential losses from risks are greater if the people in an organization do not behave carefully in their decision-making, although the implementation of credit risk management by savings and loan businesses has not been optimized.

The purpose of this study is to examine the implementation of risk management in cooperatives that are involved in the savings and loan business, and its impact on good cooperative governance and cooperative success, which can be assessed by the cooperatives' business efficiency, their members' efficiency and the impacts on environmental development.

\section{LITERATURE REVIEW}

\section{Risk Management}

Risk analysis is needed in all organizations, regardless of them being small or large scale, profit or nonprofit oriented. Management must be able to manage risk optimally in order to achieve its purpose. According to the Otoritas Jasa Keuangan (2016), risk management can be defined as a set of methodologies and procedures used to identify, measure, monitor, and control the risks arising from all the business activities. Business activities carried out by cooperatives that have a savings and loan business, namely raising fund from members and channeling back to members in the form of loans.

Risk management is the identification, assessment, and prioritization of risks followed by the coordinated and economical application of resources to minimize, monitor, and control the probability and/or impact of unfortunate events, or to maximize the realization of opportunities (Wenk, 2005). Risk management must be managed by the concepts of risk management. Figure 1, shows the cycle of risk management:

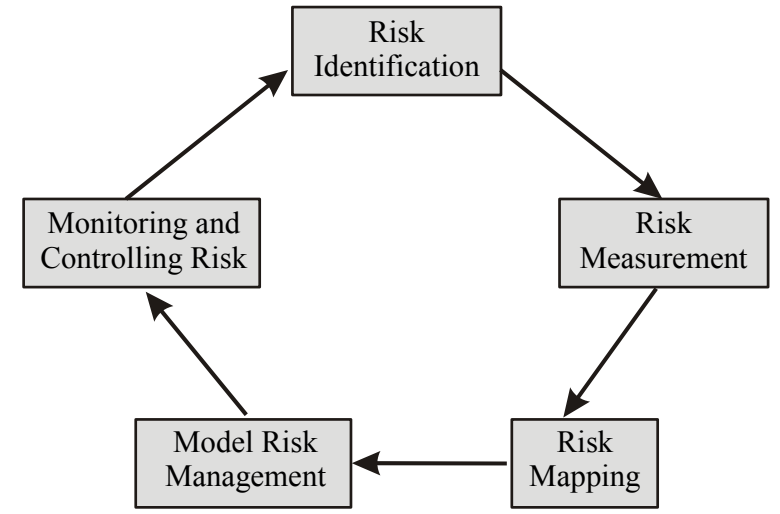

Figure 1. Risk Management Cycle Source: Djohanputro (2008)

Risk management refers to a process of identifying the loss exposures faced by an organization and selecting the most appropriate techniques for treating these particular exposures effectively (Rejda, 2003). There are many techniques available for companies to assess risks including; (Lam, 2014): (1) For the strategic risks, are their corporate and business strategies, growth strategies, or product innovations flawed or ineffectively executed? (2) For the business risks, do their annual financial and operating results not meet the management's and stakeholder's expectations? (3) For the market risks, are the prices and rates moving in a way that has negative consequences for the company? (4) For the credit risks, is there a risk that a customer, counterparty, or supplier will fail to meet their obligations? (5) For the liquidity risk, can the company raise the necessary cash to meet its requirements in a timely and cost-effective manner? (6) For the operational risk, is there a risk that people, processes, or systems will fail, or that an external event (e.g., earthquake, fire) will negatively impact the company? (7) For a compliance risk, is the company likely to violate any laws and regulations?

According to Dorfman (2007), ensuring that an organization makes cost-effective use of risk 
management first involves creating an approach built on well-defined risk management practices and then embedding them. These risks management practices include financial risk management practices, operational risk management practices, governance risk management practices, and strategic risk management practices.

Risk management does not eliminate risk but provides a platform for managing business enterprises' risks in order to minimize threats, maximize opportunities, and optimize the achievement of objectives Pearce and Robinson (2000); Hillson and Murray-Webster (2004); Gray and Larson (2006); Rejda (2011). These benefits include: superior financial performance, a better basis for strategy setting, improved service delivery, greater competitive advantage, less time spent firefighting and fewer unwelcome surprises, an increased likelihood of change initiatives being achieved, a closer internal focus on doing the right things properly, more efficient use of resources, reduced waste and fraud, and better value for money, improved innovation and better management of any contingent and maintenance activities (Wenk, 2005).

Previous research revealed that "The implementation of the framework for Enterprises Risk Management (ERM) and board equity ownership have significant positive effects on the financial and non-financial performance of financial institutions" (Ahmed and Manab, 2016), while according to Ping and Muthuveloo (2015), Shad and Lai (2015), Tahir and Razali (2011), the implementation of ERM was found to have a significant influence on firm performance. The result revealed that there is a positive relationship between total risk management and company performance, in companies which have invested in a higher level of intellectual capital.
However, other studies indicate that risk management has a significant negative effect on financial performance (Muhamad, 2017). The results do not support the hypothesis that firms which practice ERM would have a higher Tobin's Q ratio than firms which are not. Size and Return On Asset (ROA) establish a negative and significant relationship with firm value.

\section{Good Cooperative Governance}

Good corporate governance is necessary for a cooperative to achieve its objectives effectively. According to Djohanputro (2008), corporate governance may include: (1) regulatory rules and practices that determine where the company is directed and controlled; (2) specifying the distribution of the rights and obligations of various parties of commissioners, managers, holders and others; (3) clarity in the rules and decision-making procedures; and (4) not only the interests of shareholders, but also other stakeholders. Owners of capital need to be assured of getting back their investment, as production capital is highly specific; therefore corporate governance mechanisms provide this assurance. Managerial opportunism, in the form of the expropriation of investors or the misallocation of company funds, has been found to reduce the number of resources that investors are willing to put up ex-ante to finance firms (Williamson, 1985).

Governance includes the separation between the rights and obligations of the stakeholders in the company and provides clear rules and procedures for making decisions. Likewise with the implementation of cooperatives, with good governance, a cooperative's activities can be directed and controlled by its purpose. Governance can also provide the rules and procedures for making decisions that always lead to the interests of the members. According to Idroes (2008), corporate governance creates 
structures that assist banks in: (1) setting goals; (2) running daily operations; (3) considering the interests of the banks' stakeholders by operating in a healthy and sound manner; (4) adjusting to the applicable laws and regulations; and (5) protecting the interests of creditor customers.

According to Governance (2006), the principles of good corporate governance are (1) transparency - to maintain objectivity when conducting business; the company must provide material and relevant information in a way that is easily accessible and understood by the stakeholders. Companies should take the initiative to disclose not only the problems created by the current legislation but also what is important for the decision-making of the shareholders, creditors and other stakeholders, (2) accountability - the company must be able to account for its performance in a transparent and reasonable manner. Therefore, the company must be managed properly, be measurable and in accordance with the interests of the company, by taking into account the interests of the shareholders and other stakeholders. Accountability is a necessary prerequisite for achieving sustainable performance, (3) responsibility companies must comply with the laws and regulations, as well as carrying out their responsibilities to the community and the environment, so as to maintain business continuity in the long term and be recognized as good corporate citizens, (4) independence - to implement good corporate governance principles, companies must be managed independently, so that each company's organs are not dominating and cannot be interfered with by others, (5) fairness - in carrying out their activities, the company must always pay attention to the interests of its shareholders and other stakeholders, based on the principle of fairness and equality.
Corporate governance deals with a company's direction and control, in accordance with predetermined objectives; previous studies found that a strong relationship exists between the corporate governance practices under study and a firm's financial performance. Yilmaz and Buyuklu (2016), in their research, concluded that corporate governance's variables can influence a firm's performance. Another study reveals that generally, corporate governance is important for the financial performance of the company (Dominic, 2015). Todorović (2013) stated that the results of his analysis indicate that there are an obvious correlation and impact from the implementation of the principles of corporate governance on the performance of companies. Buallay et al. (2017) stated that the results of their study indicate that there is no significant impact from corporate governance's adoption on a firm's operational and financial performance, for the companies listed on the Saudi Arabian Stock Exchange.

\section{Cooperative Success}

A cooperative's success should be measured based on its objectives, by taking into account its identity which includes the values and principles of the cooperative that must be followed, so this differentiates cooperative organizations from other business entities. The primary objective of other business entities is profit. The primary task of a cooperative enterprise is to promote its members' economic well-being, thought the provision of such goods and services needed by the members (Hanel, 1985). The promotion of the members' welfare is the dominant objective of the cooperative (Dülfer, 1994). Cooperative organizations have a duty to encourage their business activities/household members through the provision of goods and services that can provide benefits for the members so that they 
will feel satisfied by the cooperative's services, thus promoting the members' economic welfare is the most important measurement of a cooperative organization's success.

The cooperative is successful when its members have improved their welfare through their participation in the cooperative. According to Hanel (2005), the success of a cooperative can be seen through three approaches commonly called the tripartite approach, which includes: business efficiency, efficiency related to development, and members' efficiency. Business efficiency is the extent of the objectives agreed by the cooperative organizations, especially as a cooperative company. Efficiency is related to development, which directly or indirectly impacts on the cooperative in the achievement of its economic development. Members' efficiency is the cooperative's orientation to create and improve its members' welfare through various supportive service activities so that the interests and goals of the members are achieved.

Based on the literature reviews and previous relevant research, this study was conducted on three cooperatives which have savings and loan businesses, the theoretical framework of this study is described in Figure 2.

\section{Hypotheses Development}

The risk is a very vulnerable problem for any organization; therefore careful management is required to reduce or minimize the impact of those risks. The implementation of risk management must be in accordance with the principles and procedures of risk management, which are expected to create good cooperative governance.

The hypotheses can be formulated as follows:

(1) There is an effect of the implementation of risk management on good cooperative governance.

(2) There is an effect of good cooperative governance on a cooperative's success.

(3) There is an effect of risk management's implementation on a cooperative's success.

(4) There is an indirect effect of risk management's implementation on a cooperative's success, through good cooperative governance as an intervening variable.

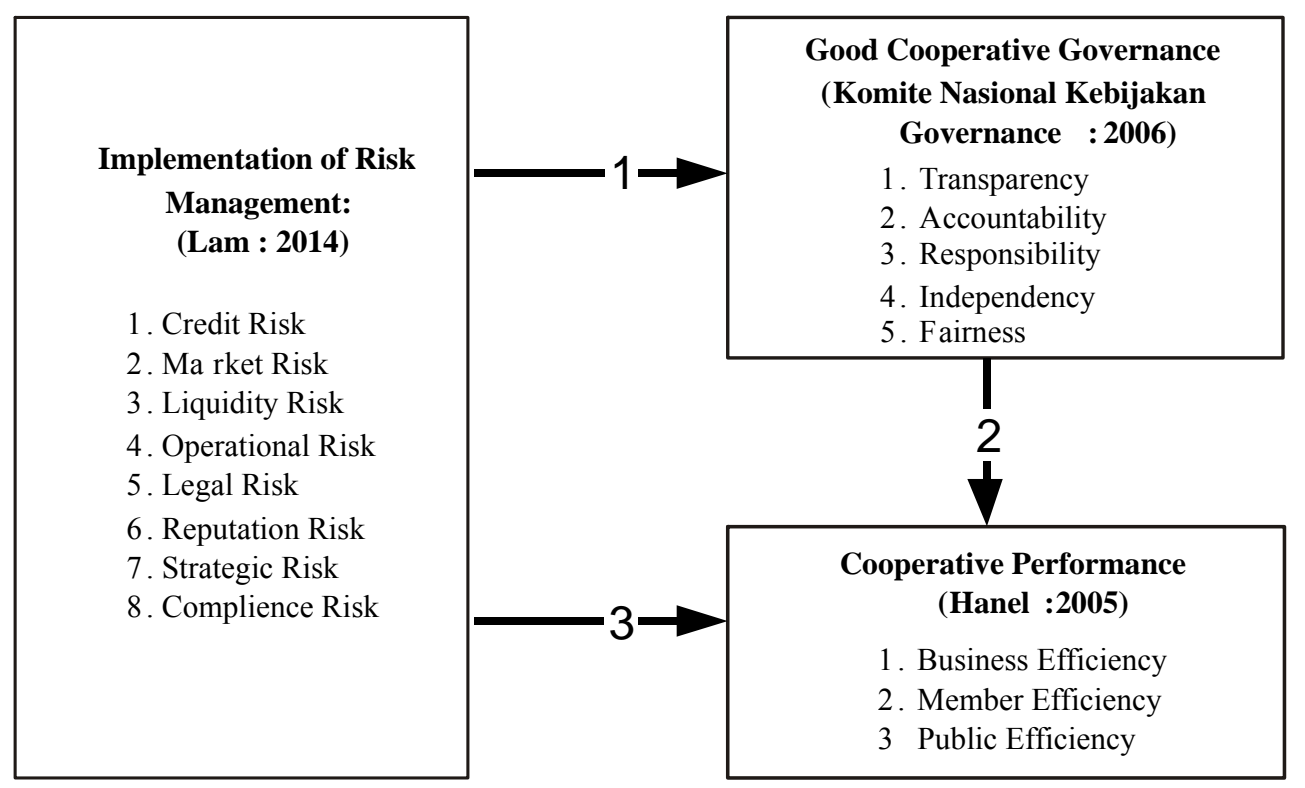

Figure 2. Theoretical Framework 


\section{METHOD, DATA AND ANALYSIS}

\section{Method}

The sample size of the respondents is 73 people, including members of the boards of directors, supervisors, managers and the employees of 3 cooperatives, which can be classified into three levels: big, medium and small cooperatives, based on their assets. KSU Bukit Ligar Bandung is a big cooperative, KSU Tandang Sari Sumedang is a medium sized cooperative and KSP Mitra Usaha Garut is a small cooperative; all the chosen cooperatives are involved in savings and loan businesses.

Data sources and the sampling's design are aimed at accomplishing the above mentioned objectives and hypotheses. The type of data for this study is ordinal data, which were collected from the respondent by questionnaires. The questionnaires' data, once collected, must be transformed into interval data using the MSI (Method Successive Interval). For the analysis method in this study, the researcher uses the implementation of risk management as the independent variable, good cooperative governance as the intervening variable and the cooperative's success as the dependent variable, while risk measurement is done by means of weighting for each possible risk.

This type of study is commonly known as descriptive quantitative research. The survey method and limits on the sample are used. Path analysis is used to explain the strength and direction of the effect of the independent variable on the dependent variable. Testing of the hypotheses is conducted by using a statistical t-test to find the significance of the independent variable to the dependent variable.

\section{Data and Analysis}

The purpose of this study is to describe the implementation of risk management in three sample cooperatives, and to examine the effect of the implementation of risk management on good cooperative governance and the success of the cooperatives. Gradually the results of this study will be explained.

\subsection{Implementation of Risk Management}

Based on the results of the study of three cooperatives that run savings and loan businesses, they have actually implemented risk management although it is still in an early stage and not in accordance with the principles of risk management. Their implementation of risk management is still limited to the application of collateral to minimize the risk of bad debts. Risk management should really be applied at the time of planning the cooperatives' business development.

The implementation of risk management studies on the three cooperative samples can be explained as follows:

a. Risk Identification

The risk that is suspected to occur in the cooperatives that have savings and loan businesses is not only limited to bad debts, but many factors can encourage the occurrence of risks. The results of the identification can be explained as follows: (1) credit risk - caused by the timeliness and the amount of loan repayments; (2) market risk - caused by the interest rate for savings and loans; (3) liquidity risk - caused by the cooperative's ability to pay both its shortterm and long-term obligations; operational risks - the failures caused by the cooperative's human resources; (5) legal risks - the risks due to weak laws governing the cooperative's operations; (6) the risk to its reputation - resulting from a lack of trust by the members toward the cooperative; (7) strategic risk - resulting from improper 
management policies; (8) compliance risk resulting from the non-compliance of the cooperative with the applicable regulations.

b. Risk Measurement

After the risks' identification is done, then the next step is to measure the amount of risk, this measurement aims to obtain the magnitude of the possibility of risk and the magnitude of the consequences caused by these risks. The measurements can be presented in the risk matrix presented in Table 1 below.

c. Risk Mapping

Risk mapping is done in order to rank or categorize the risks that may occur in a savings and loan business. Based on Table 1, it can be explained as follows:

1) The low category risks - from the eight incident risks, there are two risks that fall into the minor category. Based on Table 1, both the credit risk (Number 1) and strategic risk (Number 7) have a risk probability value of $55 \%$, this is because savings and loan businesses cannot be separated from lending activities to their members, so nonperforming loans become the most vulnerable risk for this type of business; therefore the possibility of risk is quite high. Similarly, with the strategic risk that is contained in the rules and policies for a savings and loan business, so the possibility of such an occurrence is quite high. The probability of any impact from credit risk and strategic risk is $20 \%$, so it can be concluded that both risks are included in quadrant V (Figure 3), which is the minor quadrant.

2) The very low category - there are six risks or $75 \%$ of the incentives that belong in the category of insignificant risks. Based on Table 1, the market risk (2) has a considerable risk probability when compared with the other risks that are in the very low category. The market risk here is related to the interest rate on the loans or interest rate set by the savings and loan unit; when the loan interest rate is higher, as compared to the interest rate in other financial institutions, it will affect the participation level of its members. The liquidity risk (3), operational risk (4), and compliance risk (8) have a high-risk probability when compared with the legal risk (5) and reputation risk (6).

Table 1. Risk Matrix for a Savings and Loans Business

\begin{tabular}{|c|c|c|c|c|c|c|}
\hline \multirow{2}{*}{ No } & \multirow{2}{*}{ Risks } & \multirow{2}{*}{$\begin{array}{c}\text { Risk } \\
\text { Probability }\end{array}$} & \multirow{2}{*}{$\begin{array}{c}\text { Impact } \\
\text { Probability }\end{array}$} & \multicolumn{2}{|c|}{ Quadrant } & \multirow{2}{*}{ Managemen } \\
\hline & & & & To & Categorizes & \\
\hline 1 & Credit Risk & $55 \%$ & $20 \%$ & $\mathrm{~V}$ & Minor & Prevention \\
\hline 2 & Market Risk & $50 \%$ & $10 \%$ & VI & Insignificant & Accepted \\
\hline 3 & Liquidity Risk & $45 \%$ & $20 \%$ & VI & Insignificant & Accepted \\
\hline 4 & Operational Risk & $30 \%$ & $10 \%$ & VI & Insignificant & Accepted \\
\hline 5 & Legal Risk & $5 \%$ & $5 \%$ & VI & Insignificant & Accepted \\
\hline 6 & Reputation Risk & $5 \%$ & $5 \%$ & VI & Insignificant & Accepted \\
\hline 7 & Strategic Risk & $55 \%$ & $20 \%$ & $\mathrm{~V}$ & Minor & Prevention \\
\hline 8 & Compliance Risk & $35 \%$ & $10 \%$ & VI & Insignificant & Accepted \\
\hline
\end{tabular}

Source: Primary Data (2016-2017) 
3) Based on Table 1, efforts that can be made by the management consist of two management efforts, namely prevention and acceptance. Prevention efforts can be made for credit risks and strategic risks because these risks fall into the minor quadrant. The remaining are the liquidity risk, market risk, operational risk, compliance risk, legal risk, and reputation risk, which are all included in the insignificant quadrant so that efforts can be made by the management which is acceptable to those risks.

Based on the results of the identification of the risks that may occur in the three cooperatives, risk maps can be developed, as depicted in Figure 3.

\subsection{The Effect of the Implementation of Risk} Management on Good Cooperative Governance and Success

Further analysis relating to the second purpose of this research is to study the effect of the independent variable on the dependent variable.

a. Effect of the Implementation of Risk Management on Good Cooperative Governance

Based on Table 2, it can be explained that there is a significance level of $10 \%$ obtained for the results of $t_{\text {count }}>t_{\text {table }}$ that is $1.771>1.30$. It shows that the implementation of risk management has an effect on good cooperative management, while the strong effect of the implementation of risk management on good cooperative governance, with the correlation coefficient $r=0.264$, with a significance value $<$ alpha that is $0.084<0.1$ means that the implementation of risk management has a significant effect on good cooperative governance. With the magnitude of $r^{2}$ being 0.069 or $6.9 \%$, it means that the effect of the implementation of risk management on good cooperative management is $6.9 \%$ and the remaining $93.1 \%$ is affected by other factors that are not examined here.

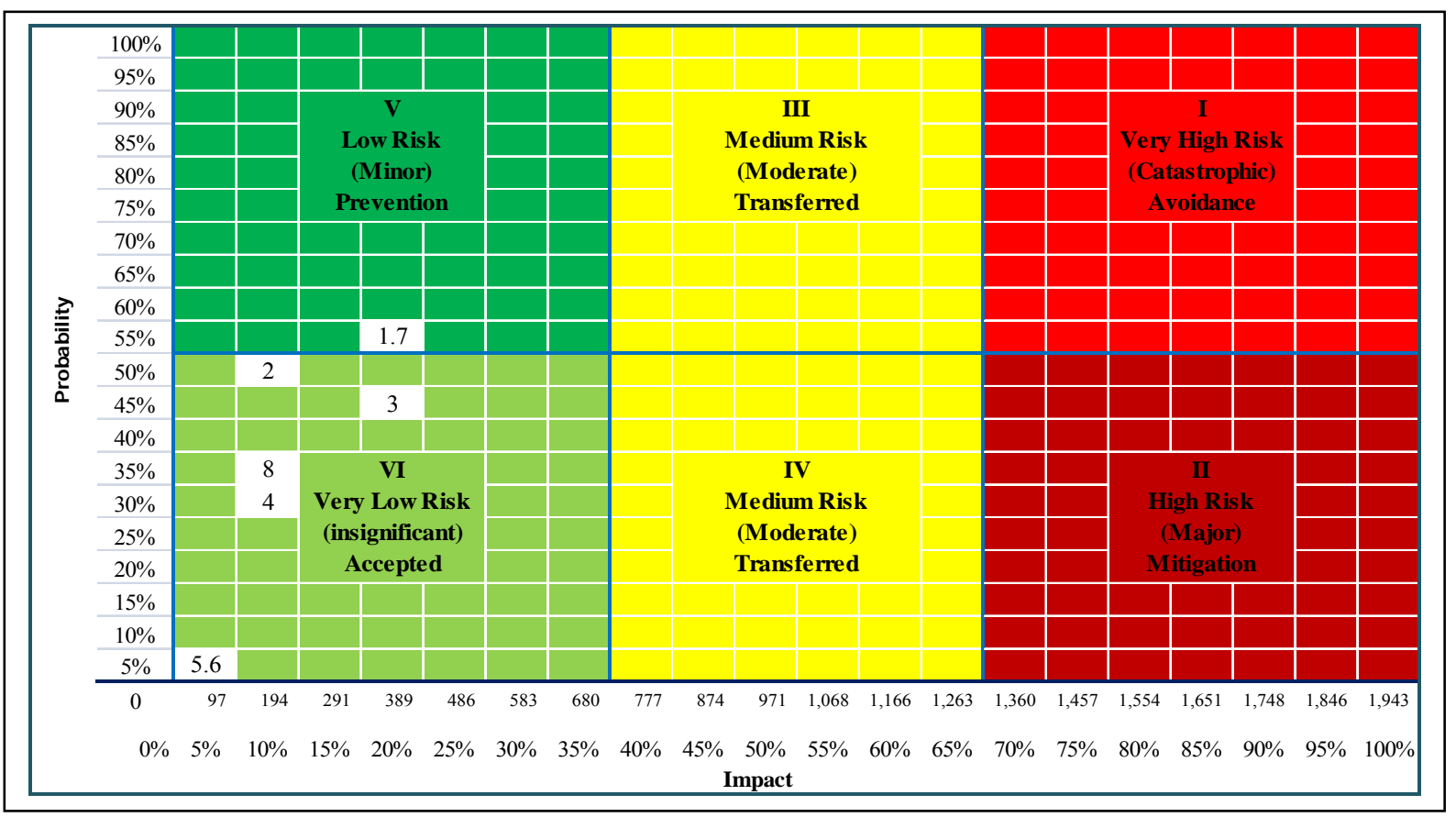

Figure 3. Risk Mapping on Savings and Loans at KSU Bukit Ligar, KSU Tandangsari, and KSP Mitra Usaha Source: Result of data processing 
Table 2. Coefficient Correlation between Variables (Direct Effect)

\begin{tabular}{clcccc}
\hline No & \multicolumn{1}{c}{ Description } & $\mathbf{r}$ & $\mathbf{r}^{2}$ & $\mathbf{t}_{\text {count }}$ & Sig. \\
\hline 1. & $\begin{array}{l}\text { Effect of Implementation of Risk Management on } \\
\text { Good Cooperative Governance }\end{array}$ & 0.264 & 0.069 & 1.771 & 0.084 \\
2. & $\begin{array}{l}\text { Effect of Good Cooperative Governance on } \\
\text { Cooperative Success }\end{array}$ & 0.601 & 0.362 & 4.879 & 0 \\
3. & $\begin{array}{l}\text { Effect of Implementation of Risk Management on } \\
\text { Cooperative Success (Direct) }\end{array}$ & 0.08 & 0.006 & 0.518 & 0.607 \\
\hline
\end{tabular}

Source: Primary Data (2016-2017)

b. Effect of Good Cooperative Governance on Cooperative Success

Based on Table 2, it can be explained by a significance level of $10 \%$ obtained for the results of $t_{\text {count }}>t_{\text {table }}$ that is $4.879>1.30$, showing that there is a significant effect of good cooperative governance $(0.000<0.1)$ on cooperative success, while the correlation coefficient of the effect of good cooperative governance on cooperative success is seen by $r=0.601$ or with the determinant coefficient $r^{2}=0.362$ or $36.2 \%$, meaning the effect of good cooperative governance variables on cooperative success is equal to $36.2 \%$ and the remaining $63.8 \%$ are influenced by other factors that are not examined here.

c. Effect of the Implementation of Risk Management on Cooperative Success

Based on Table 2, it can be explained that $t_{\text {count }}>$ $\mathrm{t}_{\text {table }}$ that is $0.518<1.30$, with a significance value of $0.607>0.1$. The implementation of risk management has no effect on cooperative success. The cooperative's success in covering the efficiency of the business's management, the efficiency related to development, and the efficiency oriented to the interests of the members is not determined by the application of risk management.

d. Effect of The Implementation of Risk Management on Cooperative Success through Good Cooperative Governance as the Intervening Variable
Based on the results of the data's processing in Table 2, it can be seen that the effect of the implementation of risk management on cooperative success, through good cooperative governance as an intervening variable, is shown by the amount of the correlation of the coefficients of the direct effects, which can be explained in Figure 4.

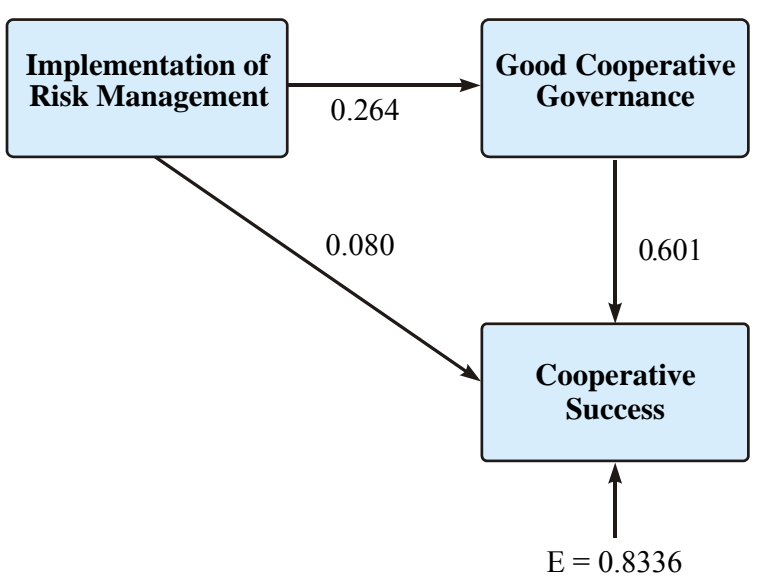

Figure 4. Direct Effects of the Implementation of Risk Management on Cooperative Success

Source: Result of data processing

Based on Figure 4, it can be explained that the magnitude of the correlation coefficient's indirect effect of the implementation of risk management on cooperative success through good cooperative governance has variables of $0.16(0.264 \times 0.601)$, which is significant, while the direct influence of the implementation of risk management on cooperative success is 0.0064 $(0.080 \times 0.080)$. The total indirect effect of the implementation of risk management on cooperative success through good cooperative management, and the direct effect of the imple- 
mentation of risk management on cooperative success are equal, overall, to $0.1664(0.16+$ $0.0064)$, and based on the result of the calculation, the overall effects given by the implementation of risk management on cooperative success are 0.1644 or $16.44 \%$ and the rest 0.8336 or $83.36 \%$ is influenced by other factors that have not been examined here. Direct effect, indirect effect and total effect can be described in table 3.

Based on table 3, can be explained that the biggest effect is an indirect effect (0.16 or $16 \%$ ). So, the success of the cooperative is determined by the application of risk management and good cooperative governance.

\section{RESULT AND DISCUSSION}

This research study revealed that there is a significant effect from the implementation of risk management in the sample of cooperatives that operate as savings and loan businesses, by covering their credit risk, market risk, liquidity risk, operational risk, legal risk, reputation risk, strategic risk and compliance risk they can create good cooperative governance (significant value $<$ alpha that is $0.084<0.1$ ). If the savings and loan businesses apply risk management then their governance will be better. Good cooperative governance can be described by its transparency (Governance, 2006), namely the transparency carried out by the management's attitude to the parties concerned, and their management of the financial statements of the savings and loan business, in accordance with the applicable accounting principles, while implementing their activities in accordance with the cooperative's identity and standard operational procedures, which frees the managers of the cooperative from the pressure or intimidation of any party and gives priority to the principles of equality and fairness.

As an indirect effect of the implementation of risk management on a cooperative's success through good cooperative governance (indirect effect $=0.16$ ), the cooperative's success is determined by its good cooperative governance which has been undertaken by the cooperative's management; because creating good cooperative governance requires the implementation of risk management. This implementation is required to enable the cooperative's management to minimize the risks that may occur related to their savings and loan activities, in addition to the implementation of good risk management, which will be useful for the management in its decision-making associated with their savings and loan business activities. This is in accordance with Pradana (2014) who stated that risk management is an integral component of good management and decision-making, at every level in an organization. The results of this study can encourage management to always prioritize a prudential attitude in their implementation of risk management; in the hope, it will be able to create good cooperative governance, namely governance that is always oriented to the achievement of goals. When a cooperative has good governance it can attract its members to participate in the cooperative, both as owners (owner) and as users (user).

Table 3. Coefficient Correlation between Variables (Indirect Effect)

\begin{tabular}{clccc}
\hline No & \multicolumn{1}{c}{ Description } & $\begin{array}{c}\text { Indirect } \\
\text { Effect }\end{array}$ & $\begin{array}{c}\text { Direct } \\
\text { Effect }\end{array}$ & $\begin{array}{c}\text { Total } \\
\text { Effect }\end{array}$ \\
\hline $\begin{array}{l}\text { Effect of Implementation of Risk Management on } \\
\text { Cooperative Success through Good Cooperative } \\
\text { Governance as a Variable Intervening }\end{array}$ & 0.16 & 0.0064 & 0.1664 \\
\hline
\end{tabular}

Source: Primary Data (2016-2017) 


\section{CONCLUSION}

Based on the above discussion, it can be concluded that:

1. In the sample of savings and loan cooperative businesses, the implementation of risk management can be started with its identification stage, measurement, mapping, management model, monitoring, and risk control. Based on the results identified, the measurement and mapping of a savings and loan business's risks can be categorized as either minor risks (the credit risk and strategic risk), while the market risk, liquidity risk, operational risk, legal risk, reputation risk and compliance risk all come under the category of insignificant risks.

2. The implementation of risk management has a significant effect on good cooperative governance; it shows that if the cooperative implements risk management it will have an impact on good cooperative governance, Good cooperative governance has a significant effect on a cooperative's success; it shows that a cooperative's success is determined by good cooperative governance. However, the implementation of risk management has no effect on a cooperative's success; it shows that a cooperative's success is not determined by the implementation of risk management, the implementation of risk management indirectly affects a cooperative's success through good cooperative governance. This indirect effect is greater when compared to its direct effect. This shows that a cooperative's success is determined by good cooperative governance.

\section{LIMITATIONS AND SUGGESTIONS}

This research has implications for both the theoretical and practical aspects. As far as the theoretical aspect is concerned, this research does not only highlight the importance of the implementation of risk management for its effect on good cooperative governance and cooperative success. If the cooperative's manager makes a decision, especially those related to achieving success for the cooperative, risk management has to be implemented through good cooperative governance.

Good cooperative governance is an effort to achieve the goals that have been set, namely the welfare of the members. Good cooperative governance can separate the rights and obligations of the members of a cooperative, such as the right of the members to receive services and benefits from their cooperative, while the obligation is to capitalize the cooperative's business activities and provide ideas related to the progress of the cooperative, while the right of the management is to receive wages for their hard work and the obligation to manage the cooperative in accordance with the mandate given by the members.

This research can be useful in encouraging the sustainability of cooperative organizations in Indonesia generally and for KSU Bukit Ligar Bandung, KSU Tandang Sari Sumedang and KSP Mitra Usaha Garut in particular. Cooperative organizations have to implement risk management to realize the cooperatives' governance and to achieve the cooperatives' goals, especially the members' welfare through the services offered to members. Suggestions for further research based on several of the limitations of this research include identifying the risks in the various aspects of the cooperatives' business activities in detail.

\section{REFERENCES}

Ariff, M. S. B. M., Zakuan, N., Tajudin, M. N. M., Ahmad, A., Ishak, N., \& Ismail, K. (2014). A framework for risk management practices and organizational performance in higher education. Review of Integrative 
Business and Economics Research, 3(2), 422.

Ahmed, I., \& Manab, N. A. (2016). Influence of enterprise risk management framework implementation and board equity ownership on firm performance in Nigerian financial sector: An initial finding. IOSR Journal of Business and Management (IOSRJBM), 18(1), 61-68.

Buallay, A., Hamdan, A., \& Zureigat, Q. (2017). Corporate governance and firm performance: evidence from Saudi Arabia. Australasian Accounting, Business and Finance Journal, 11(1), 78-98.

Danoshana, S., \& Ravivathani, T. (2013). The impact of the corporate governance on firm performance: A study on financial institutions in Sri Lanka. Merit Research Journal of Accounting, Auditing, Economics and Finance, 1(6), 118-121.

Djohanputro, Bramantyo. (2008). Risiko korporat terintegrasi [Integrated corporate risk]. Jakarta: PPM.

Dominic, Ochoi Ong'ondo and Florence Memba. (2015). Effect of corporate governance practices on financial performance of public limited companies in Kenya. International Journal of Management and Commerce Innovations, 3 (1), 122-132.

Dorfman, Mark. S. (2007). Introduction to risk management and insurance. Englewood Cliffs, New Jersey: Prentice Hall.

Dülfer, E., and Laurinkari, J. (1994). International handbook of cooperative organizations. Germany: Vandenhoeck \& Ruprecht.

Fadun, O. S. (2013). Risk management and risk management failure: Lessons for business enterprises. International Journal of Academic Research in Business and Social Sciences, 3(2), 225.

Gray, E.W. andC.F. Larson. (2006). Project management: The managerial process (3rd ed.). New York: McGraw-Hill.

Hanel, A. (1985). Basic aspects of cooperative organizations and policies for their promotion in developing countries. Selbstverl.

(2005). Organisasi koperasi [Organization of cooperatives]. Yogyakarta:
Graha Ilmu.

Hillson, D., and Murray-Webster, R. (2004). Understanding and managing risk attitude. In Proceedings of 7th Annual Risk Conference, held in London, UK (Vol. 26). Retrievedfrom, http://www.kent.ac.uk/ scarr/events/finalpapers/Hillson $\% 20 \% 2 \mathrm{~B} \% 2$ 0MurrayWebster.pdf.

Indroes Ferry, N. (2008). Manajemen risiko perbankan [Risk management in banking]. Jakartat: PT. Raja Grafindo Persada.

Komite Nasional Kebijakan Governance (KNKG). 2006. Pedoman umum good corporate governance Indonesia [A guideline for Good Corporate Governance: Indonesia]. Indonesia: KNKG.

Lam, J. (2014). Enterprise risk management: from incentives to controls. New Jersey: John Wiley andSons, Inc.

Mohammed, H. K., and Knápková, A. (2016). The impact of total risk management on company's performance. Procedia-Social and Behavioral Sciences, 220, 271-277.

Muhamad, Zakir., Djayani Nurdin, Nurhayati Haris and Sulaeman Miru. (2017 The effect of risk management and good corporate governance on financial performance and its impact on the firm value. IOSR Journal of Business and Management, 19 (5), 94-105.

Otoritas Jasa Keuangan. (2016). Peraturan Otoritas Jasa Keuangan No. 18 Tahun 2016 Tentang Penerapan Manajemen Risiko Bagi Bank Umum [Financial Service Authority regulation no. 18 year 2016: Implementation of risk management for conventional banks]. Jakarta.

Pearce, J. A., Robinson, R. B., and Subramanian, R. (2000). Strategic management: formulation, implementation, and control. Columbus: McGraw-Hill.

Ping, T. A., \& Muthuveloo, R. (2015). The impact of enterprise risk management on firm performance: Evidence from Malaysia. Asian Social Science, 11(22), 149.

Pradana, Yana Ayu. (2014). Application of risk management to the realization of good corporate governance at company insurance. Trikonomika, 13 (2), 195-2014.

Putra, A., \& Simanungkalit, R. M. (2014). The Impact of Implementation Good Corporate 
Governance to Firm Value (Evidence from Indonesia Public Banking Sector). Review of Integrative Business \& Economic Research, 4(1), 95-102.

Rejda, E., G. (2003). Principles of risk management and insurance. New York: Pearson Education Inc.

(2011). Introduction to risk management and insurance (11th ed.). Upper Saddle River, NJ: Prentice Hall.

Santoso, D. (2008). Kegagalan penerapan good corporate governance pada perusahaan publik di Indonesia [Failures of implementing good corporate governance in Indonesian public corporations]. Jurnal Hukum IUS QUIA IUSTUM, 15(2).

Shad, M. K., \& Lai, F. W. (2015). Enterprise risk management and firm performance validated through economic value added factors. International Journal of Economics and Statistics, 3, 148-154.
Tahir, I. M., \& Razali, A. R. (2011). The Relationship between enterprise risk management (ERM) and firm value: Evidence from Malaysian public listed companies. International Journal of Economics and Management Sciences, 1(2), $32-41$.

Todorovic, I. (2013). Impact of corporate governance on performance of companies. Montenegrin Journal of Economics, 9(2), 47.

Yilmaz, C., \& Buyuklu, A. H. (2016). Impacts of Corporate Governance on Firm Performance\&58; Turkey Case with a Panel Data Analysis. Eurasian Journal of Economics and Finance, 4(1), 56-72.

Wenk, D. (2005). Risk Management and Business Continuity. Overview and Perspective Journal of the Chartered Insurance Institute, 3(3), 234-246.

Williamson, Oliver E. (1985). The economic institutions of capitalism. New York: The Free Press.

Disclaimer: The Journal of Indonesian Economy and Business and its Board of Editors are not responsible for any errors and flaws found in this article. The author(s) take full responsibility for their work. 